\title{
FRENCH BIOLOGICAL PHILOSOPHY OF TECHNOLOGY AS A CANDIDATE PERSPECTIVE FURTHERING DESIGN METHODOLOGY
}

\author{
Mulder, Sander \\ Delft University of Technology
}

\begin{abstract}
A first exploration is conducted to what the French biological philosophy of technology perspective has to offer to the field of design methodology. If this French perspective is combined with contemporary speculative pragmatism a generative design methodology emerges offering novelty in what is sensed as important in a design situation. Within this perspective, drawing upon the late French philosopher Gilbert Simondon, technical objects have their own mode of existence and their own trajectory of development apart from human intention.

Designers working with such a generative design methodology follow the constitutive value of openness and attune to the regulative value of techno-aesthetic judgments. By way of a 'vignette + ', a paradigmatic example from a real case, a more encompassing argument is made towards design situations where a sophisticated machine is 'inserted' into a domestic setting.

The example taken is the use of an artificial kidney machine in a domestic setting and the development of a novel machine with a design team. Four aspects were sensed as important in the unfolding design situation and directions for further research are discussed.
\end{abstract}

Keywords: Design methodology, Design methods, Simondon, Technology, Techno-aesthetics

\section{Contact:}

Mulder, Sander

Delft University of Technology

Product Innovation Management

The Netherlands

s.s.mulder@tudelft.nl 


\section{INTRODUCTION}

In this paper we conduct a first exploration what the French biological philosophy of technology perspective has to offer to the field of design methodology. If this French perspective is combined with contemporary speculative pragmatism a generative design methodology emerges offering novelty in what is sensed as important in a design situation. Within this perspective technical objects have their own mode of existence and their own trajectory of development apart from human intention. Designers working with such a generative design methodology follow the constitutive value of openness and attune to the regulative value of techno-aesthetic judgments.

French philosophy of technology is approached in this paper mainly via the late philosopher Gilbert Simondon (1924-1989) as he created a novel understanding of the relation between technology, humans and nature by arguing for a separate mode of existence of technical objects. At the core Simondon provides a theory of qualitative change (De Boever et al., 2009, p.38) focussing on the evolution of the relation between mankind and technical objects. A contemporary take on Pragmatism is added to allow for speculative thought beyond human needs. This take on Pragmatism is suggested by Didier Debaise and Isabelle Stengers and we argue it helps to bring French philosophy towards designers who try to sense what is important in an unfolding design situation.

In section 2 we elaborate on French biological philosophy of technology mobilizing concepts and theory towards the research question. Section 3 addresses the chosen method for this paper: a vignette taken from a design situation backed by a transcribed interview. Section 4 presents the results and Section 5 discusses the contribution to design methodology and Section 6 presents the conclusions.

\section{FRENCH BIOLOGICAL PHILOSOPHY OF TECHNOLOGY}

French philosophy of technology is approached in this paper mainly through Gilbert Simondon's philosophical project. His early work is translated only recently into English (cf. Simondon 2017), but his influence can be read via well-known contemporary French philosophers: Gilles Deleuze, Bruno Latour and Bernard Stiegler. Simondon is regaining attention in philosophy, science and technology studies, communication, new media and culture studies, gender studies and political science leading to more translations of work into English and an increasing amount of dissertations, papers and books of which a selective read is referenced in this paper. Canadian philosopher Brian Massumi argues that this new attention is caused by digital technology and especially bio-technology as advancements in both fields increasingly force us to question not so much who we are but rather who we become bringing ontology, or more precisely ontogenetics, to the fore (De Boever et al., 2009). Simondon's philosophy of technology is different from post-phenomenology where technical objects mediate between humans and the world (cf. the works of Don Ihde and Peter-Paul Verbeek) and it is different from the analytical meta-physical approach where artefacts have a dual nature intertwining a material and an intentional structure (cf. the works of Peter Kroes and Anthonie Meijers). Simondon proposes a dynamic view where technical objects are defined by their genesis (Guchet 2017) and therefore Simondon had to develop an ontogenetic account. The biological philosophy of technology instantiates new perspectives for instance on the role of designers in nano-technology (Loeve 2018) but in this paper we relate to a more mundane design situation.

In the next section 2.1 to 2.5 we introduce some key concepts resulting in the research question in 2.6. The philosophy of Simondon is introduced by drawing upon four theses formulated by Schick and elaborating on Simondon by additional secondary literature (Schick 2017). Further we follow the position of Xavier Guchet arguing to import an ethical perspective into the work of Simondon (Guchet 2018, pp.238-239). In order to bring French philosophy to an unfolding design situation we embrace speculative pragmatism (Debaise and Stengers 2017). 


\subsection{French biological philosophy of technology perspective explained in four theses}

The biological perspective in French philosophy of technology comes to the fore in the following four theses formulated by Schick summarizing Simondon's project. In the first thesis:

1. 'the individual is an absolute starting point $[\ldots]$ in a heuristic $[\ldots]$, metaphysical and ontological sense: It is always involved in creating, structuring and inventing its relation with its milieu." (Schick 2017). Schick continues his first thesis that human individuals create, structure and invent '...via analogy. They search relations that are similar to their own mental functioning and realize them within nature. Knowledge has to be understood as a specific kind of individuation, i.e. as an action of a living being which is structuring its milieu.' (Schick 2017, p.55, emphasis removed)

Schick' second thesis accounts for humans, animals and plants:

2. 'The individual is building structures within itself and outside of itself: The individual individuates constantly and thus remains alive. It transforms itself and its milieu simultaneously.' (Schick 2017, p.55, emphasis removed)

The third thesis draws a parallel between technical objects and the living:

3. 'Technical objects are themselves individuals and milieus. The application of the method of analogy allows one to describe technical objects in the same terms as living beings. [...]' (Schick 2017, p.55)

The fourth and last thesis introduces an ethics:

4. 'Ultimately, the philosophy of Simondon is resulting in an ethical attitude towards materiality and technical objects based on the ontological principle of openness. This ethical principle also applies to the structure of technical objects. Technical objects should be open objects instantiating participation.' (Schick 2017, p.56, emphasis in original).

In addition to the notion of individual in the first thesis, it is more suitable to speak of "individuation" to express and emphasize the process or operation of becoming individual. As Schick points out as well, Simondon devises a method of analogy that allows to move between domains such as physics, biology, the socio-psychic and philosophy by investigating operations instead of structures (cf. Barthélémy 2012, pp.204-205). The concept "operation" is important. The individual is creating, structuring and inventing by way of "operations that are structured, and therefore structures [that] can serve as a support for other operations'2 (Duhem 2010, p.47). The method of analogy or method of operations takes as object operations but is in itself also an operation (Schick 2017, p.56).

Simondon uses the term "technical objects" as he wanted to investigate operations that constitute individual beings. "Technology" has a different connotation in Simondon's work and is of less importance here. In addition to theses 2 and 3 the explanation of Guchet and Bensaude-Vincent relates milieu to design: an engineer "imagines" a machine operating in and with its associated environment, for instance in the example Simondon discusses in detail: the cooling of streaming water on the outside of a Guimbal-turbine in addition to the force of water to make the turbine rotate generating oil-pressure that lubricates the machine, transports heat and prevents by over-pressure water from leaking into the turbine (example taken from Simondon 1958) [...] 'Design and operation are not two independent tasks.' (Guchet and BensaudeVincent 2008, p.37)

\footnotetext{
${ }^{1}$ Individual here accounts for man, animal, plant and even technical objects. The notion 'milieu' should be taken here as an internal milieu inside the living and an accompanying 'associated milieu' surrounding the living that has the potential to become structured. The associated milieu is actively created, that takes part in individuation and is at the same time a result of individuation. Milieu is then different from the larger concept 'nature' or 'environment' but at the same time cannot be separated from human being as it co-evolves with us.

2 'des opérations qui se structurent, et donc des structures qui peuvent servir de support à d'autres opérations' Duhem, L. (2010) 'Introduction à la techno-esthétique (version longue)', Archée, 71.
} 
The fourth thesis needs some further elaboration. Simondon stresses that technical objects have their own ontological status (Simondon 1958). They evolve towards openness, but not because they adapt to human demands. 'The technical object actually evolves not when it adapts to the context and to the goals it is produced for [...], but rather when it institutes a dynamic relationship between two milieus, the technical and the geographical' (Bardin 2015, p.133). The Guimbal-machine can be taken as an example. The insertion in a dam institutes a dynamic relation between the turbine and the streaming water of a river and allows the water to participate in a new relation at a specific geographic location. Simondon also argues that there is an inherent drive in technical development towards openness as inventors tend to replace different parts of machines with fewer parts performing multiple operations at once. The Guimbal-turbine illustrates that: the water is imagined as functioning as kinetic energy and as a coolant making separate cooling obsolete.

\subsection{Techno-aesthetics and design}

Before we arrive at a notion of design within the French philosophy of technology, we need to explain techno-aesthetics as a mode of thought and judgment: 'Because there is no natural matching between functioning and use, design is always based on techno-aesthetic choices...'3 (Loeve 2018, p.381). In the perspective of Simondon an aesthetics has a connotation of a unique, singular and local insertion in the world that can be sensed in the present. The Guimbal-turbine for instance is inserted in a particular dam in a particular river and one needs to go there in order to sense the aesthetics of that insertion in that geographic location. The operation of the Guimbal-machine however is detachable from that location and can also take place in another river with a dam. That leads to another aesthetic insertion at that specific geographic location: 'The technical object [, on the contrary,] as a tool, [does not fit, because it] can act everywhere, work everywhere (Duhem 2010, p.63). However, technical detachment cannot be fully separated from aesthetics and vice versa. In case of a work of art: 'It is clear that this opposition between aesthetic insertion and technical detachment is essential to understand to what extent there is technicality in art, but different from the technicality of technical objects in themselves. ${ }^{4}$ (Duhem 2010, p.63). Design then has both an aesthetic insertion and a technical detachment aspect and both are combined in 'techno-aesthetics. 'Techno-aesthetics can be defined as the study and design of apparatuses that transform the functioning of the sensible. [...] As a design practice, it would afford intellectual, practical and emotional grasps on [nano]-enabled experiences. (Loeve 2018, p.381). Loeve continues '...design should reconsider and perhaps reclaim its role as techno-aesthetics' (Loeve 2018, p.381). 'This techno-[a]esthetic is one of the concepts that best expresses the value judgments of a man driven by the technical mentality described above. Thus, ethics and [a]esthetics are necessary counterparts to one another, and to the philosophy of technology.' (response of Bart Chabot in De Vries et al., 2014).

\subsection{Import of normative perspective over ethics}

French professor of ethics of techniques Xavier Guchet argues that Simondon's framework needs an import of ethics drawing on George Canguilhem (1904-1995) who argued that our biological rooting in life is a primary source of norms, a vital normativity. This vital normativity can be observed in case of survival (Guchet 2018, p.253). To emphasize that ethics in this perspective can take place on a biological level without deliberate (cognitive) contemplation as Aislinn O'Donnell argued in her PhD thesis: 'Ethics is not just a process of deliberating about actions. It is a process of becoming-active. Ethics, that is, ontology.' (O'Donnell 2001, p.205). Simondon goes as far that there is a demand to make machines more open so they operate more analogue to how humans operate (Schick 2017, pp.74-75). The same could be said of the techno-aesthetic. 'The techno-aesthetic is a contemplation of action. [...] The technoaesthetic prefers the surprising to the predictable [...]' (Chabot 2013, p.142). Various authors point out that Simondon is ambiguous in what should prevail: ethics or aesthetics (Chabot 2013; Clarizio 2016; Guchet 2018; Loeve 2018). Both Clarizio and Guchet suggest that ethics should be primary.

${ }^{3}$ Loeve quotes from p. 39, Simondon, G. (1960-1961). Psychosociologie de la technicité. In G. Simondon (2014), Sur la technique (pp. 27-129). Paris: Presses Universitaires de France

4 'On voit bien que cette opposition entre insertion esthétique et détachement technique est primordiale pour comprendre dans quelle mesure il y a de la technicité dans l'art, mais différemment de la technicité des objets techniques en eux-mêmes.' 'Duhem, L. (2010) 'Introduction à la techno-esthétique (version longue)', Archée, 71. 


\subsection{Openness: invention and regulation}

The notion of openness in the philosophy of Simondon requires some further explanation. Schick describes it as follows:

'The ethical principle is derived out of his ontology: Living beings have to maintain their metastability to remain alive. They have to build open systems with their milieus and create sense. Openness is therefore a value in itself, since it is the basis upon which beings remain alive. This ethical principle does not, however, rely upon a binary logic that establishes the categorical opposition of good and bad. It rather creates infinite degrees of values.' (Schick 2017, p.72)

In Simondon's work, openness in technical objects is produced and invented by individuals, but regulative values such as techno-aesthetics are also important. (Mills 2014, p.6).

\subsection{Information, invention and aesthetic judgment in technical objects}

The concept of 'information' is adopted as a key methodological tool by Simondon (Bardin 2015, p.21). As we saw in thesis (1) above, for Simondon 'thought itself becomes action, praxis, and a risky enterprise' [...] 'going back to Bergson's concept of intuition, and making it into a theory of invention' (Bardin 2015, p.51). A profound and complicated position of Simondon is summarized here: that information is actively invented by an individuating individual by way of intuition. This plays out differently to some extent in the aesthetic and the technological. The aesthetic e.g. in a work of art is an 'operation which converts a potential of form in structure is an operation [...], i.e. neither inductive nor deductive, but intuitive. The work of art is therefore not the realization of an intention but the structuring of a potential according to an intuition.' (Duhem 2010, p.39, emphasis in original). As we have seen, a technical invention like the Guimbal-machine also is intuitive, but to understand the beauty of technical operations knowledge is required.

'This is why the discovery of beauty in technical objects cannot be left to perception alone. It is necessary for the function of the object to be understood and thought. To say this in another way, a technical education is necessary in order for the beauty of technical objects to appear as part of the way in which technical concepts are inserted into the universe and as important points of this universe.' (Simondon 1958, p.186) "Technical beauty" is, therefore, always the result of a mixture of cognitive judgment (involving theoretical and practical knowledge) and aesthetic judgment (involving sensible appreciation.)' (Duhem 2012, fn. 4, empasis in original).

\subsection{Research question}

If we think then within the French biological philosophy of technology perspective, we see a possibility for a generative design methodology where one operation supports other operations to emerge. To acknowledge the situatedness of the designer in an unfolding design situation, yet leaving room for other modes of existence such as that of technical objects developing without human intention, we draw on speculative pragmatism trying to get rid of anthropocentrism. 'For the sense of importance cannot be a human privilege in the face of an indifferent world' (Debaise and Stengers 2017, p.17). Our research question then is: What is sensed as important in an unfolding design situation if we follow the constitutive value of openness and the regulative value of techno-aesthetics?

\section{METHODOLOGY AND METHOD}

Within this paper a more traditional research method is used namely a vignette as a paradigmatic example in order to build a more encompassing argument while at the same time doing justice to the 'empirical and artifactual turn' in the philosophy of technology. The vignette is emblematic for a wider range of situations and is common in the philosophy of technology. E.g. Peter-Paul Verbeek describes pre-natal diagnostic imaging technology to argue how technology mediates between humans and the world and how such technology is moral in that mediation (Verbeek 2008). The vignette used in this paper stands for the techno-aesthetic insertion of "sophisticated open machines" in domestic settings resulting in networked medical devices that are increasingly sensitive to outside information, adjusting to emerging situations of vital importance and becoming an inherent part of the design process. In addition to Verbeek's 
illustrative way of using a vignette we provide additional evidence through empirical data. In the Appendix we share a short interview excerpt from a design situation that was recorded while the author was engaged in a real design project to develop a novel medical device. In total the author conducted eleven interviews in domestic settings and two in professional settings. The excerpt chosen illustrates what is sensed as becoming important within a design situation as it unfolds. The author follows the generative aspect of a techno-aesthetic sensation and knowledge in a subsequent meeting.

The interview excerpt was taken as we think it provides a stronger account than a vignette alone. The interaction between the author, a colleague design practitioner and two people being interviewed in their domestic context is written down and gives stronger evidence to follow the techno-aesthetic regulative value as it emerges. The interview was recorded in 2015, the excerpt was translated by the author for this paper from Dutch into English and anonymised at a few points. We cover just a few minutes of interview. The interviewed couple gave consent. The commissioning organisation for the design project, the Dutch Kidney Foundation, gave consent as well as long as no sensitive data is shared, no pending patent applications or other intellectual property rights are violated and no commercial harm results from publication. The interview excerpt and subsequent project meeting are selected in hindsight. So far, the authors have not found accounts in literature describing a design situation where the techno-aesthetic regulative value is unfolding. How the generative and processual of the techno-aesthetic can be worked with as it emerges in a design situation, rather than in hindsight, is a methodological question that will be addressed in Section 5 under discussion.

\section{RESULTS}

In the Appendix the excerpt is presented. The setting and some key data are shared in section $4.1 \mathrm{~A}$ subsequent meeting the next day is shared in less detail in Section 4.2. Recording of that meeting was not possible due to a non-disclosure agreement. In Section 4.3 the interview and meeting are then related to concepts and theory of the French biological philosophy of technology as introduced earlier on.

\subsection{Contextual interview setting}

The author collaborated as a designer with a project leader, hereafter referred to respectively with 'Author (or author)' and 'Colleague'. They were part of a project team that developed and designed a portable medical device and accompanying care concept including training and services such as remote monitoring. The purpose of the contextual interview was twofold. First to deepen understanding how existing medical machines and services intervened in daily life. Second to imagine in what ways future daily life might be affected by a novel transportable machine that was beyond a proof-of-principle carried out by a team of engineers and scientists.

The interviewees are a couple, here referred to as 'Woman' and 'Man' and the interview was conducted in their home. The Woman had (and still has) a serious chronic disease. She received medical treatment from an artificial kidney machine every night for approximately eight hours while she was asleep. For this reason, part of the interview was conducted in the master bedroom to develop insight in that specific setting. The excerpt selected covers a few minutes taking place in the bedroom while the author, Colleague, Man and Woman are present.

The artificial kidney was positioned next to the couple's bed on the woman's side. The Man sleeps next to her. Before going to bed he connects her artery to the artificial kidney and he starts the treatment. The Woman and Man received a half year training to perform this complicated medical treatment independently at home. They both felt confident to make some small adjustments to the machine and these adjustments become part of the unfolding situation.

\subsection{Techno-aesthetic regulative value emerging in design practice}

As said, this excerpt in the Appendix is situated in the bedroom. The artificial kidney machine was turned on and an alarm sound went off. This was a trigger for Colleague to ask a question about the sound level of the machine. The Man and Woman explain that the noise level of the device is disturbing in their bedroom setting and they show two simple modifications they carried out to lower 
the noise level of the machine. These modifications enabled them to sleep better during the treatment. The modifications were done in such way that the medical treatment of the blood of the Woman was not affected. The modifications were done at the verge of the technical working of the machine evidencing their know-how of the machine while operating. During the excerpt the Man also suggests a mechanical modification of the machine to the author and Colleague.

The day after this interview the author and Colleague were having a meeting with two representatives of the commissioning organisation. A Senior Scientist Medical Equipment explained at some point during the meeting that the new machine will be programmed in such way that it will constantly adapt treatment to ensure the best medical result. The author checks with the scientist to what extent this will lead to a continuously varying noise level generated by the novel device. The scientist confirms this will be the case indeed. The author then infers that this constant variation of noise may be an issue for the quality of sleep if the machine is placed next to a bed while conducting a treatment at night. What follows is a short discussion to what extent it is feasible to allow a patient to choose between optimal blood treatment and good sleep. A couple of options are devised to lower the noise level. The suggestion from the couple we interviewed was brought to the fore as well.

\subsection{Relate interview data to concepts and theory}

From the interview with the man and woman and the subsequent meeting with the scientist the following was sensed as important in the design situation:

- Vital normativity was present in the background, both the author, Colleague, Man and Woman knew that the artificial kidney was prolonging the Woman's "openness" so to say as her blood was treated to prevent it from saturating. Vital normativity also came to the fore when sleep was discussed: the noise level prevented the couple on a biological level to sleep and on a more psychic level as they were more alert during their sleep for potentially dangerous situations emerging from the treatment.

- Aesthetic insertion became a topic of the interview because the author and Colleague were interviewing in the master bedroom when an alarm went off. That level of noise triggered an interview question that was not prepared. A similar kind of emergence took place the next day when the author came to realize a constantly varying noise level would be an aesthetic insertion of potentially lower quality as it may interfere on a vital (biological) or psychic level.

- Technical detachment happened when the Man explained how he was able to modify the machine on the verge of affecting its technical operation. Furthermore he suggested a mechanical modification of the machine based on knowledge of how sound is transduced by mechanical bodies and is amplified by resonating in cavities. He could do so as knowledge of technical operations allows to detach, he was self-educated as an amateur musician and he was practical enough to insert a clothes peg and use a strap to lower the noise level of the artificial kidney. Both the author and Colleague were trained as design engineers and recognized the elegance of the modification.

- The artificial kidney was modified by the Man in order to serve better. The machine was adapted towards utility: lower the noise level for the Woman. The geographic-technical relation of the machine was not altered by the modifications. One imagined mechanical modification was suggested to alter the interior of the machine but we can conclude that the geographic-technical relation of the machine was not altered.

\section{DISCUSSION}

The French biological philosophy of technology completed with an ethics and a speculative pragmatic stance led the author to becoming more attentive in retrospect. In hindsight the author was able to follow how the constitutive value of openness led to new operations and new structures in the design meeting the next day. The following qualities were sensed as important from within the design situation stated in such way it can be carried over to other design situations:

- $\quad$ Openness of the machine,

- $\quad$ allowing for new possibilities with regards to vital normativity

- Techno-aesthetic judgment of an insertion in an existing situation

- Technical detachment based on existing knowledge and (self-)education 
This raises the following questions for further research:

- In an existing design situation how can we follow the constitutive value of openness that is inherently coming along with a novel machine?

- In an invasive situations vital normativity is coming to the fore but how is this sensed as important in other design situations such as gaming?

The described setting was closely linked to a situation where survival was at stake. Still, vital normativity goes deeper than that. It relates to how the living is information and is reflexive. The additional perspective of vital normativity to the socio-psychic and technical is a contemporary development in the biological philosophy of technology and its implications need further attention.

- Until we have equal relations with machines that are analogue to man, how can designers deal with the tension between situated particular techno-aesthetic judgements and the possibility of technical detachment?

- How can we educate both designers and other people in expressing their techno-aesthetic judgments and facilitate both in the modification of geographic-technical insertions?

It remains unclear how the artificial kidney could be altered in such way that the geographic-technical relation progresses while at the same time a better aesthetic insertion is arrived at in the bedroom setting. A deeper understanding is needed how to 'play' with technical operations together with designers, engineers and perhaps users without directly focussing on utility. A first attempt for a triggering assignment has been tried out in an academic conversational workshop lead by the author. This setting recently leading to a new notion of giving rise to values in a design situation allowing for the own mode of existence of machines. The question then is: 'How can humans and machines coemerge in ways that neither could alone?' (Mulder et al., 2018).

- Further support from theory is required especially with regards to methodology and method. We see the 'vignette plus' method as a proxy for becoming more attentive and attuned in an unfolding situation. How to follow the emergence of regulative value as a scientist, as an educator and as a practitioner designer?

\section{CONCLUSIONS}

In hindsight it was possible to sense four aspects of importance in a design situation while following the constitutive value of openness and the regulative value of techno-aesthetics in a particular design situation: vital normativity, aesthetic insertion, technical detachment and geographic-technical relation.

This explorative study is a first indication that there is a possibility for a design methodology within the French biological philosophy of technology. Such a perspective allows for an ethics that is inherent in design methodology: it allows for a constitutive value of openness and is followed by a regulative value expressed via a techno-aesthetic judgment by designers acknowledging the own modes of existence of mankind and technical objects and the progress towards a more equal relation.

Design in this paper is provisionally defined by stating that engineers, inventors, craftsman and artists can imagine and built sophisticated machines, but designers might have an education that equips them to move from techno-aesthetic judgment to technical detachment and vice versa. This definition of design needs further elaboration and scrutiny.

Further research directions are discussed including a suggestion for design education. Additional research is needed in unfolding design situations to sense what is important when we devise sophisticated networked machines. How are we designed by what we design? to paraphrase Anne-Marie Willis' notion of ontological design (Willis 2006, p.70).

\section{ACKNOWLEDGEMENTS}

The author thanks the interviewed couple for their openness and the commissioning organisation the Dutch Kidney Foundation for their approval to use data. Former colleagues at Design Innovation Group are thanked for being part of the project team and their consent. Furthermore my appreciation goes to readers of earlier versions for their friendly critique, in particular Stella Boess, Kees Dorst, Bregje van Eekelen, Ehsan Baha and Frithjof Wegener. To conclude I thank the two anonymous reviewers for their constructive feedback. No financial support is related to this study. 


\section{REFERENCES}

Bardin, A. (2015), Epistemology and Political Philosophy in Gilbert Simondon. Individuation, Technics, Social Systems., Springer, Netherlands.

Barthélémy, J.-H. (2012), "Fifty key terms in the work of Gilbert Simondon", in De Boever, A., Murray, A., Roffe, J. and Woodward, A., eds., Gilbert Simondon: Being and Technology Edinburgh University Press.

Chabot, P. (2013), Philosophy of Simondon: between technology and individuation, Bloomsbury, London [u.a.].

Clarizio, E. (2016), "The contribution of French biological philosophy of technology to the debate on technological mediation”, in Theorizing Technological Mediation Symposium, University of Twente, November 17th, 2016.

Cross, N. (1984), Developments in Design Methodology, Wiley, Chester.

De Vries, M.J. (2008), “Gilbert Simondon and the dual nature of technical artifacts”, Techné: Research in Philosophy and Technology, Vol. 12 No. 1.

De Vries, M.J., Feenberg, A., De Boever, A. and Hoel, A. (2014), "Book Symposium on The Philosophy of Simondon: Between Technology and Individuation", Philosophy \& Technology, pp. 1-26, available: http://dx.doi.org/10.1007/s13347-013-0144-5.

Dorst, K. (1997), "Describing design: a comparison of paradigms", thesis (PhD), Delft University of Technology.

Duhem, L. (2010), "Introduction à la techno-esthétique (version longue)", Archée, Vol. 71.

Duhem, L. (2012), "Thinking aesthetic reality (with Simondon)”, SubStance, Vol. 41, pp. 16-31.

Guchet, X. (2018), Toward an Object-Oriented Philosophy of Technology in Loeve, S., Guchet, X. and Bensaude-Vincent, B., eds., French Philosophy of Technology, 1st ed., Springer International Publishing AG, part of Springer Nature, Cham, Switzerland. pp. 237-256.

Guchet, X. and Bensaude-Vincent, B. (2008), Nanomachine: Technological Concept or Metaphor? in Jotterand, F., ed., Emerging Conceptual, Ethical and Policy Issues in Bionanotechnology Springer Science \& Business Media, p. 264.

Loeve, S. (2018), Design and Aesthetics in Nanotechnology in Loeve, S., Guchet, X. and Bensaude-Vincent, B., eds., French Philosophy of Technology, Springer International Publishing AG, part of Springer Nature, Cham, Switzerland. pp. 361-384.

Mills, S. (2014), “Gilbert Simondon: Causality, ontogenesis \& technology”, thesis (PhD), University of the West of England.

O’Donnell, A. (2001), "An ethics of the pre-individual”, thesis (PhD), University of Warwick.

Schick, J.F.M. (2017), "Theaters of Individuation. Gilbert Simondon and the Interrelations of Ethics, Techniques, and Ontology", Journal of Badiou Studies, Vol. 5.

Simondon, G. (1958), Du mode d'existence des objets techniques, Aubier.

Simondon, G. (1992), The Genesis of the Individual in Crary, J. and Kwinter, S., eds., Incorporations (Zone 6) Zone Books.

Simondon, G. (2017), On The Mode of Existence of Technical Objects, 1st ed., translated by Malaspina, C. and Rogrove, J., Univocal Publishing, Minneapolis.

\section{APPENDIX: EXCERPT OF CONTEXTUAL INTERVIEW}

1. [Colleague] 'So this is the noise level you hear at night?'

2. [Man] 'Yes. Well.... So when it's working, it's because of that single-needle system, those valves that're there, those valves that make a lot of noise. All night long. Clung. Clung. Clung. And that goes at a fairly high pace, so that's really annoying.

3. [Colleague] Would it be desirable that it should be less?'

4. [Man \& Woman] 'Yes, yes'.

5. [Man] 'But that is actually inherent in the fact that he works with those buffer vessels.' [...]

6. [Woman] 'They already have some kind of silencers in them.'

7. [Man] 'Really expensive. [...] But, I have such a strap over here. That's not an official... modification of the work. [...]

8. [Author 1] 'But why are you doing that then?'

9. [Man] 'Well, when you press such a valve, it just makes less noise. In fact the front of the machine resembles a big plastic drum and the valves are attached to it and you hear it like clung clung clung'.

10. [Author 1] 'Ah, it's like a sound box. [...]

11. [Man] 'It's just like hitting a drum. In fact, I think it would matter a lot if those clamps came through a hole in the lid and were stuck on the interior of the machine. If you open this door 
you'll see that this front is filled with all these small clamps. So, the clothes pegs down there make it sound less like a drum.' [laughter].

12. [Colleague] 'I always like these kinds of solutions.'

13. [Man] 'Yes, I think so, then make a kind of plastic threshold that, when you close the door, will dampen it, but yes, no [organisation] technicians have yet come up with it, so I do it with half clothes pegs. We have a lot of them.'

14. [Woman] 'And that just makes a big difference.

$[\ldots]$

15. [Man] 'This one does it every 40 seconds.

16. [Author 1] 'And the machine actually makes a kind of repertoire at night, I'll just say, is that right or wrong?'

17. [Man] 'When you start dialysis, it sounds one pump clung, the other pump clung, and that goes on all night.'

18. [Author 1] 'So at the moment that deviates you hear that too?'

19. [Woman] 'Yes yes yes. We sleep there on.'

20. [Man] 'So it is not like a washing machine that he runs a certain program two hours and that he then will rinse or something. He just keeps giving the same action for eight hours.'

21. [Woman] 'And we sleep there on so you hear at a certain moment oh something is not going well.'. 